\title{
Expression of B-Cell Markers in Classical Hodgkin Lymphoma: A Tissue Microarray Analysis of 330 Cases
}

\author{
Alexandar Tzankov, M.D., Annette Zimpfer, Ann-Christine Pehrs, Alessandro Lugli, M.D., \\ Philip Went, M.D., Robert Maurer, M.D., Stefano Pileri, M.D., Stephan Dirnhofer, M.D. \\ Institute of Pathology, University of Basel, Basel (AZ, A-CP, AL, PW, SD), Switzerland; Institute of \\ Pathology, University of Innsbruck, Innsbruck, Austria (AT, AZ, A-CP); Institute of Pathology, Triemli \\ Hospital, Zurich (RM), Switzerland; and Pathologic Anatomy and Lymphoma Unit, Institute of \\ Hematology and Clinical Oncology "L. \& A. Seràgnoli," University of Bologna, Bologna, Italy (SP)
}

Hodgkin and Reed-Sternberg cells of classical Hodgkin lymphoma arise from B-lymphocytes. However, classical markers of the B-cell phenotype, such as CD20, are present only in about $25 \%$ of the cases. The aim of the present study was to assess expression of the B-cell-related antigens CD20, CD79a, and CD138 in classical Hodgkin lymphoma using a tissue microarray consisting of $\mathbf{3 3 0}$ classical Hodgkin lymphoma cases. Expression of CD15, CD20, CD30, CD79a, CD138, and latent membrane protein 1 of Epstein-Barr virus was assessed by immunohistochemistry, and the methodology was validated by direct comparison of CD20 expression on the tissue microarray cores with corresponding large sections. The influence of the number of arrayed sample cores on the obtained expression levels of CD20 was analyzed by comparing the results from single, duplicate, and triplicate cores. Twohundred fifty-three $(77 \%)$ of the 330 cases were morphologically representative. CD20 was expressed in 84 cases (33\%), CD79a in $26(10 \%)$, and CD138 in 2 (1\%), respectively. CD20 and CD79a were co-expressed in 16 cases $(P<.005)$, and expression of CD20 correlated inversely with CD15 $(P<.01)$. Comparing the tissue microarray results with those from conventional sections for expression of CD20 yielded a concordance of $94 \%$ (63/67). Examining one, two, and three cores from individual cases revealed positivity for CD20 at $24 \%(61 /$ $253), 32 \%(82 / 253)$, and $33 \%(84 / 253)$, respectively. We conclude that B-cell markers are expressed in $\mathbf{3 8 \%}$ of classical Hodgkin lymphoma in the follow-

Copyright (C) 2003 by The United States and Canadian Academy of Pathology, Inc.

VOL. 16, NO. 11, P. 1141, 2003 Printed in the U.S.A.

Date of acceptance: July 21, 2003.

Authors AT and AZ contributed equally to this work.

Address reprint requests to: Stephan Dirnhofer, M.D., Institute of Pathology, University of Basel, Schönbeinstrasse 40, CH-4031 Basel, Switzerland; fax: 4161265 3194; e-mail: sdirnhofer@uhbs.ch.

DOI: 10.1097/01.MP.0000093627.51090.3F ing rank order: $\mathrm{CD20}>\mathrm{CD} 79 \mathrm{a} \gg \mathrm{CD} 138$. The use of two cores per tissue sample renders the tissue microarray technology effectively representative and thus very useful for high-throughput evaluation of heterogeneously expressed markers in classical Hodgkin lymphoma.

KEY WORDS: B-cell markers, CD138, CD20, CD79a, Hodgkin lymphoma, Tissue microarray.

Mod Pathol 2003;16(11):1141-1147

Recent molecular studies showed that Hodgkin and Reed-Sternberg cells of classical Hodgkin lymphoma originate from germinal center or postgerminal B cells (1-9). Phenotypic examinations revealed that 5 to $100 \%$ of Hodgkin and ReedSternberg cells in classical Hodgkin lymphoma express different B-cell markers, such as CD19, CD20, CD40, CD79a, CD138, bcl-6, B-cell specific activator protein (PAX5), and MUM1 (1-22). Expression of the classical B-cell marker CD20 in classical Hodgkin lymphoma reportedly varied from 5\% to $>80 \%(9,10,13,15,16,18-22)$. Typically, CD20 appears to be expressed on a variable proportion of Hodgkin and Reed-Sternberg cells with variable staining intensity, often weaker than in normal reactive B cells $(9,15,20)$.

Positivity for CD20 in classical Hodgkin lymphoma can lead to serious diagnostic difficulties in the differential diagnosis of nodular lymphocytepredominant Hodgkin lymphoma and T-cell-rich B-cell lymphoma, two clinically distinct but morphologically closely related diseases $(8,9,23)$. Moreover, expression of CD20 has become also of clinical interest: Rituximab seems to be an efficient treatment option for relapsed CD20-positive Hodgkin lymphoma (24), and we have recently demonstrated that CD20-positive classical Hodgkin lymphoma cases have better failure-free and overall survival (18). 
Immunohistochemical studies revealed that other markers of B-cell differentiation, such as CD79 and CD138, also known as syndecan-1, are expressed on Hodgkin and Reed-Sternberg cells in 10 to $48 \%$, and 45 to $100 \%$ of cases, respectively; however, expression of CD138 has been studied exclusively on frozen tissue $(1-3,11,12,21)$.

The tissue microarray technique allows simultaneous analysis of a large number of tumors for in situ expression of individual markers under highly standardized conditions $(25,26)$. Recently, its accuracy has been proven for a variety of markers, such as CD5, CD10, CD15, CD20, CD23, CD30, CD43, CD44, bcl-2, bcl-6, p53, cyclin D1, cyclin D3, cyclin $\mathrm{E}$, and the latent membrane protein 1 of EpsteinBarr virus, clearly demonstrating that it is also a reliable tool for the analysis of large lymphoma populations (27-30). We previously reported the largest classical Hodgkin lymphoma-tissue microarray yet constructed and validated its representativeness for predominantly homogenously and/or consistently expressed markers on a large proportion of Hodgkin and Reed-Sternberg cells, such as latent membrane protein 1 and CD30 (30). This tissue microarray, comprised of 330 classical Hodgkin lymphoma cases of all subtypes, was now used to analyze the predominantly heterogeneously and inconsistently expressed B-cell markers on Hodgkin and Reed-Sternberg cells such as CD20, CD79a, and CD138 and to correlate them to CD15, which is typically also inconsistently expressed both in individual cells and individual cases, and latent membrane protein 1 .

\section{MATERIALS AND METHODS}

\section{Samples}

Three hundred thirty classical Hodgkin lymphoma cases collected between 1985 and 2001 at the Institutes of Pathology at the Universities of Basel (Switzerland), Bologna (Italy), and Innsbruck (Austria) and at the Triemli Hospital of Zurich (Zurich, Switzerland) were included. All cases were reclassified according to the WHO classification (9) and consisted of 197 nodular sclerosis, 105 mixed cellularity, 5 lymphocyte depleted, 10 lymphocyterich, and 13 unclassifiable classical Hodgkin lymphoma.

\section{Tissue Microarray Constructions}

For tissue microarray construction, a hematoxylin and eosin-stained slide was made from each block to define representative tumor regions, particularly Hodgkin and Reed-Sternberg cell hot spots, if present. Tissue cylinders (cores) with a diameter of $0.6 \mathrm{~mm}$ were punched from the tumor areas of each block and brought into a recipient paraffin block using a precision instrument (Beecher Instruments, Silver Spring, MD), as described elsewhere $(25,26)$. Five-micrometer sections of these tissue microarray blocks were transferred to an adhesive-coated glass slide system (Instrumedics Inc., Hackensack, NJ). To overcome the problem of tissue microheterogeneity and increase the number of evaluable cases, we punched the donor tissue blocks either two (Innsbruck and Basel samples) or three times (Bologna and Zurich samples). Only tissue cores containing at least two unequivocal Hodgkin and Reed-Sternberg cells were considered representative. Cases with only one pathognomonic cell were excluded from further examination. In addition, morphology was corroborated by CD30 immunostains.

\section{Immunohistochemistry}

Bound secondary antibodies were visualized by standard avidin-biotin-peroxidase techniques using diaminobenzidine as chromogen (ABC-Elite; Vector Lab., Burlingame, CA). Deparaffinization with xylene and incubation with the primary antibody lasted 24 hours. Antibodies against CD15, CD20, CD30, CD79a, and CD138, their dilutions and pretreatment conditions, are listed in Table 1. For the B-cell markers CD20, CD79a, and CD138, staining in $>10 \%$ of Hodgkin and Reed-Sternberg cells or in $>50 \%$ of the Hodgkin and Reed-Sternberg cells (cases with $<10$ tumor cells) was considered positive (18). For positive control staining, normal tonsils (CD20, CD79a, and CD138) were used. For negative control experiments, the primary antibodies were omitted.

\section{Statistics}

Statistical analysis was performed using the Statistical Package for Social Sciences (SPSS). $\chi^{2}$ was applied to estimate the interrelations between the

TABLE 1. Antibodies and Antigen-Retrieval Techniques Applied

\begin{tabular}{|c|c|c|c|}
\hline Antibody & Retrieval & Source & Dilution \\
\hline CD15 & Pressure cooker, $100^{\circ} \mathrm{C}, 30$ minutes, citrate & DAKO & $1: 500$ \\
\hline CD20 & Microwave oven, $800 \mathrm{~W}, 30$ minutes, citrate & DAKO & Prediluted \\
\hline CD30 & Pressure cooker, $121^{\circ} \mathrm{C}, 5$ minutes, citrate & DAKO & $1: 50$ \\
\hline CD79a & Pressure cooker, $121^{\circ} \mathrm{C}, 3$ minutes, citrate & NeoMarkers & 1:1600 \\
\hline CD138 & Microwave oven, $800 \mathrm{~W}, 30$ minutes, citrate & DAKO & $1: 300$ \\
\hline Latent membrane protein 1 & $0.1 \%$ pronase, 4 minutes & DAKO & $1: 1000$ \\
\hline
\end{tabular}


different expression profiles, and the pairedsamples $t$ test, to compare the gain of information after examination of one, two, and three tissue microarray cores. $P$ values of $<.05$ were considered significant. The agreement between immunohistochemical results obtained on the tissue microarray and on conventional full-tissue sections was assessed using the $\kappa$ statistics; in general, a $\kappa$-value of $>0.75$ implied an excellent agreement.

\section{RESULTS}

As shown elsewhere (30), 258 of the 330 classical Hodgkin lymphoma-cases (78\%) were representative by hematoxylin and eosin morphology. The vast majority thereof (230 cases, $89 \%$ ) contained $>10$ Hodgkin and Reed-Sternberg cells, sometimes $>50$ (Figs. 1, 2A-B). Reasons for noninformative spots included samples devoid of tissue (21 cases, $6 \%$ ) or tumor cells (51 cases, 15\%; Fig. 1). Thus, the morphologically evaluable cases consisted of 150 nodular sclerosis, 83 mixed cellularity, 10 lymphocyte depleted, 5 lymphocyte rich, and 10 unclassifiable classical Hodgkin lymphomas (Table 2). Five cases of 150 nodular sclerosis classical Hodgkin lymphomas were inadequately fixed and could not be evaluated, so the final number of immunohistochemically evaluable cases was 253 (77\%). The classical markers CD30 and CD15 were expressed in 97\% (245/253) and 66\% (167/253), respectively (30). Sixty cases $(24 \%)$ were associated with an Epstein-

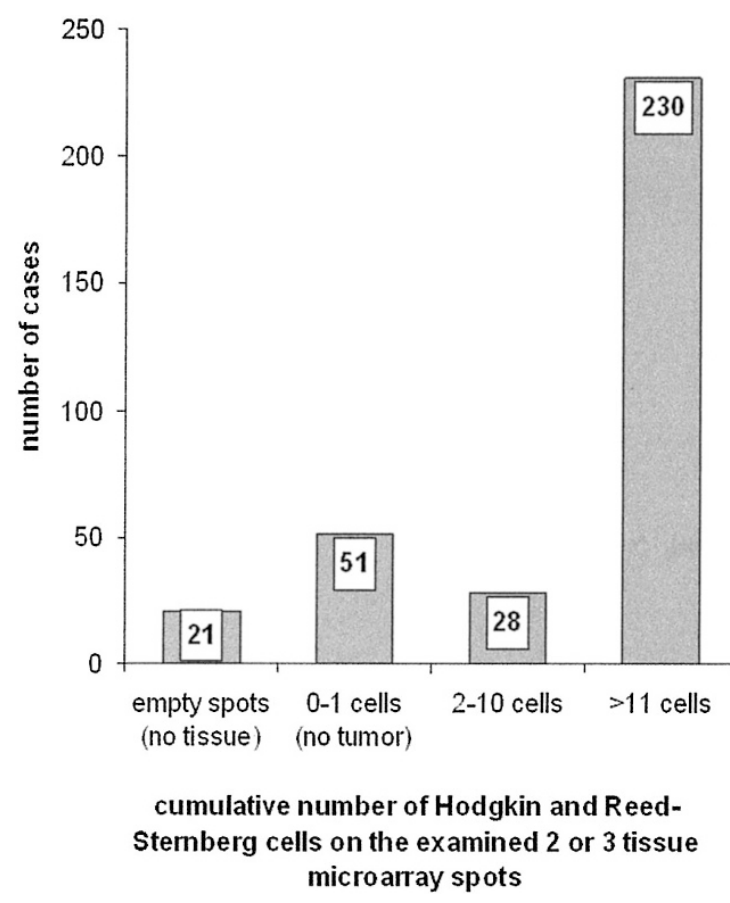

FIGURE 1. Distribution of the total numbers of Hodgkin and ReedSternberg cells on the examined two or three tissue microarray spots from individual cases of classical Hodgkin lymphoma.
Barr virus infection, as assessed by the expression of latent membrane protein 1 (Table 2) (30).

Eighty-four of the 253 cases (33\%) were positive for CD20 (Table 2). CD20 staining was weak to moderate compared with the strongly stained reactive B-lymphocytes in the background and was confined to the cell membrane of the Hodgkin and Reed-Sternberg cells with a submembranous rim (Fig. 2C-D). In positive cases, 20 to $90 \%$ of Hodgkin and Reed-Sternberg cells expressed CD20 (median, $40 \%$ ). There was no significant correlation between Epstein-Barr virus infection and expression of CD20 in Hodgkin and Reed-Sternberg cells $(P=.055)$. However, expression of CD20 correlated inversely with CD15 expression: 37/167 CD15-positive cases (22\%) expressed CD20, versus 47/86 (55\%) CD20positive cases in the CD15-negative group $(P<.01)$. Twenty-six cases (10\%) expressed CD79a (Table 2). In these cases, 10 to $30 \%$ of Hodgkin and ReedSternberg cells expressed CD79a (median, 20\%), with moderate staining intensity localized to the cell membrane and the cytoplasm (Fig. 2E-F). In 16 cases, Hodgkin and Reed-Sternberg cells coexpressed CD20 and CD79a $(P<.005$; Fig. 3). CD138 was expressed in two cases $(1 \%)$ that were negative for CD20 and CD79a, with a moderate staining intensity in about half of the Hodgkin and Reed-Sternberg cells, and strongly stained plasma cells were scattered throughout the background infiltrate (Fig. 2G-H). Altogether, 96 of the 253 classical Hodgkin lymphoma cases (38\%) expressed at least one B-cell marker.

To assess the influence of the number of arrayed cores from the same tissue specimen on the tissue microarray sensitivity, we compared the results for expression of CD20 and CD79a of single, duplicate, and triplicate cores, the latter for the cases of Bologna and Zurich $(n=88)$ that were punched three times as explained in our Materials and Methods. Examination of one random core showed average expression ratios of $24 \%$ for CD20 (61/253) and $7 \%$ for CD79a (18/253), respectively. Examination of two cores significantly increased these values, to $32 \%$ and $10 \%(82 / 253$ and $25 / 253, P<.0001)$, respectively. Evaluation of all three cores augmented the previous values only incrementally, by $1 \%$ and $0.5 \%(84 / 253$ and $26 / 253, P>0.1)$, respectively (Fig. 4).

To validate the classical Hodgkin lymphomatissue microarray methodology, we directly compared CD20 expression on the tissue microarray to that assessed on conventional full tissue sections in 68 cases (all from Innsbruck). Seventeen of 67 evaluable cases $(25 \%)$ were positive on the tissue microarray compared with 21 (31\%) on the full tissue sections. Ninety-four percent $(63 / 67)$ of the cases were concordant. Six percent (4/67), all containing $<10$ Hodgkin and Reed-Sternberg cells per 

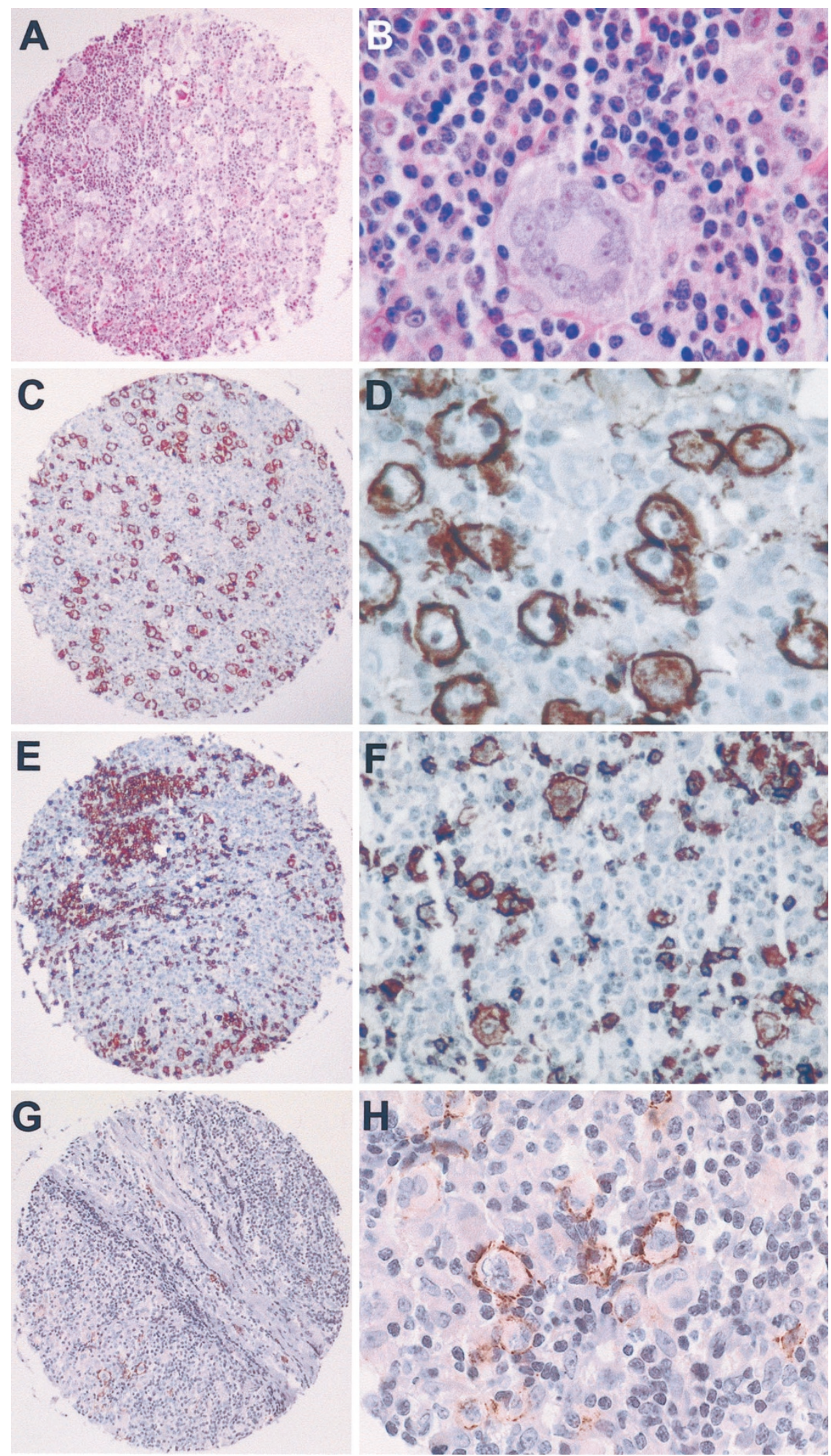

FIGURE 2. A, classical Hodgkin lymphoma tissue microarray core, hematoxylin and eosin stain, 120×. B, Reed-Sternberg cell in a tissue microarray core, hematoxylin and eosin stain, 600×. C, CD20 expression in classical Hodgkin lymphoma; immunoperoxidase stain. Note multiple Hodgkin and Reed-Sternberg cells stained in the overview; 120×. D, CD20 expression in Hodgkin and Reed-Sternberg cells, immunoperoxidase stain. Note one negative Hodgkin and Reed-Sternberg cell in the middle upper part of the picture, 600×. E, CD79a expression in classical Hodgkin lymphoma, immunoperoxidase stain, 120×. F, CD79a expression in Hodgkin and Reed-Sternberg cells and reactive background lymphocytes, immunoperoxidase stain, 350×. G, CD138 expression in a nodular sclerosis classical Hodgkin lymphoma, immunoperoxidase stain. Note isolated positive plasma cells in the sclerosis bundle, 120×. H, CD138 expression in Hodgkin and Reed-Sternberg cells, immunoperoxidase stain. Note the four CD138-negative Hodgkin and Reed-Sternberg cells, 400×. 
TABLE 2. Expression of CD15, CD20, CD30, CD79a, and Latent Membrane Protein 1 (LMP1) of Epstein-Barr Virus in Classical Hodgkin Lymphoma

\begin{tabular}{|c|c|c|c|c|c|c|c|c|c|c|c|}
\hline \multirow{2}{*}{$\begin{array}{c}\text { Hodgkin Lymphoma } \\
\text { Subtype }\end{array}$} & \multirow{2}{*}{$\begin{array}{c}\text { Number of } \\
\text { Evaluable } \\
\text { Cases }\end{array}$} & \multicolumn{2}{|c|}{ CD30 Positive } & \multicolumn{2}{|c|}{$\begin{array}{l}\text { CD15 } \\
\text { Positive }\end{array}$} & \multicolumn{2}{|c|}{$\begin{array}{c}\text { CD20 } \\
\text { Positive }\end{array}$} & \multicolumn{2}{|c|}{$\begin{array}{c}\text { CD79a } \\
\text { Positive }\end{array}$} & \multicolumn{2}{|c|}{$\begin{array}{c}\text { LMP1 } \\
\text { Positive }\end{array}$} \\
\hline & & $\mathrm{n}$ & $\%$ & $\mathrm{n}$ & $\overline{\%}$ & $\mathrm{n}$ & $\overline{\%}$ & $\mathrm{n}$ & $\overline{\%}$ & $\mathrm{n}$ & $\%$ \\
\hline Nodular sclerosis & 145 & 141 & 97 & 102 & 70 & 41 & 28 & 11 & 8 & 26 & 18 \\
\hline Mixed cellularity & 83 & 83 & 100 & 48 & 58 & 35 & 42 & 14 & 17 & 27 & 33 \\
\hline Lymphocyte rich & 10 & 6 & 60 & 4 & 40 & 3 & 30 & 1 & 10 & 1 & 10 \\
\hline Lymphocyte depleted & 5 & 5 & 100 & 4 & 80 & 1 & 20 & - & & 3 & 60 \\
\hline Unclassified & 10 & 10 & 100 & 9 & 90 & 4 & 40 & - & & 3 & 30 \\
\hline Total & 253 & 245 & 97 & 167 & 66 & 84 & 33 & 26 & 10 & 60 & 24 \\
\hline
\end{tabular}

two cores, were discordant, that is, positive for CD20 on conventional sections and negative on the tissue microarray. The $\kappa$-value was 0.85 , indicating an excellent concordance.

\section{DISCUSSION}

Although the B-cell origin of Hodgkin and ReedSternberg cells in classical Hodgkin lymphoma is now well established (1-9), the frequency of immunohistochemically detectable expression of classical B-cell markers remains controversial. For example, CD20-expression in various studies ranges from 5 to $>80 \%(9,10,13,15,16,18-22)$. The discrepancy between the obvious genotypic B-cell origin of classical Hodgkin lymphoma and the lack of phenotypically demonstrable B-cell marker expression can be explained by molecular alterations leading not only to down-regulation of single B-lineage markers but to profound defects in B-lineage gene expression $(31,32)$.

Using the novel tissue microarray technology, we found CD20 expression in 33\% of our large series of 253 classical Hodgkin lymphomas, a distribution in line with the results of other studies performed on conventional large sections $(9,10,13,15,16,18-$ 22). Moreover, direct validation demonstrated that the expression of CD20 on the tissue microarray matched in $94 \%(63 / 67)$ the corresponding conventional full tissue sections. This result is even better than the $83 \%$ concordance for CD20 reported recently by Garcia and coworkers (27). In our study, discordances due to decreased sensitivity were observed in 4 cases $(6 \%)$, all with $<10$ Hodgkin and Reed-Sternberg cells per two tissue microarray cores. This can be explained by the known focal expression of CD20 in classical Hodgkin lymphoma in a median proportion of approximately $50 \%$ of the Hodgkin and Reed-Sternberg cells (9, 10, 13, 15, 16, 18-22). All matching cases contained $>30$ Hodgkin and Reed-Sternberg cells per two tissue microarray cores. Obviously, for the most critical combination of focally expressed markers (CD20) in heterogeneous tumors (classical Hodgkin lymphoma), paucity of tumor cells on the cores can lead to decreased tissue microarray sensitivity. However, this can be largely compensated for by repeatedly punching representative tumor areas from the donor block. For comparison, we observed a concordance of $100 \%$ between the tissue microarray and conventional large sections for the expression of latent membrane protein 1 , a marker that is homogenously and consistently expressed in all Hodgkin and Reed-Sternberg cells of Epstein-Barr virus-associated classical Hodgkin lymphoma (30).

To assess in detail the influence of the number of arrayed sample cores on the representativeness of the tissue microarray, we compared the expression of CD20 and CD79a after evaluation of one $(0.28$ $\mathrm{mm}^{2}$ tissue size), two $\left(0.57 \mathrm{~mm}^{2}\right)$, and three cores $\left(0.85 \mathrm{~mm}^{2}\right)$ from individual cases. Ninety-eight percent of the overall positivity of $33 \%$ for expression of CD20 was reached after examining at least two cores, compared with $73 \%$ after evaluation of one random core $(P<.0001)$. Evaluation of the third core was not significantly more informative-two additional cases of 253 appeared to be CD20 positive $(P=.158)$. Similar observations were made for CD79a. Therefore, our conclusions for the use of the tissue microarray technique for classical Hodgkin lymphoma are that it is advisable to punch every tissue block of classical Hodgkin lymphoma samples at least twice and that the representativeness of the samples is not further enhanced by inclusion of multiple tissue punches in the tissue microarray.

In this large tissue microarray study, we found no correlation between expression of CD20 in classical Hodgkin lymphoma and Epstein-Barr virus infection, even when analyzed separately for cases with mixed-cellularity classical Hodgkin lymphoma, in agreement with our previous observations on a limited patient population (18). However, we observed an inverse correlation between the distribution of CD15 and CD20 $(P<.01)$ that remains to be elucidated.

Interestingly, despite being expressed in virtually all mature circulating B-cells and, to a lesser degree in germinal center B cells (33), CD79a was expressed in only $10 \%$ of classical Hodgkin lymphoma, compared with $33 \%$ for CD20. This result is within the range of reports from the literature $(8$, 


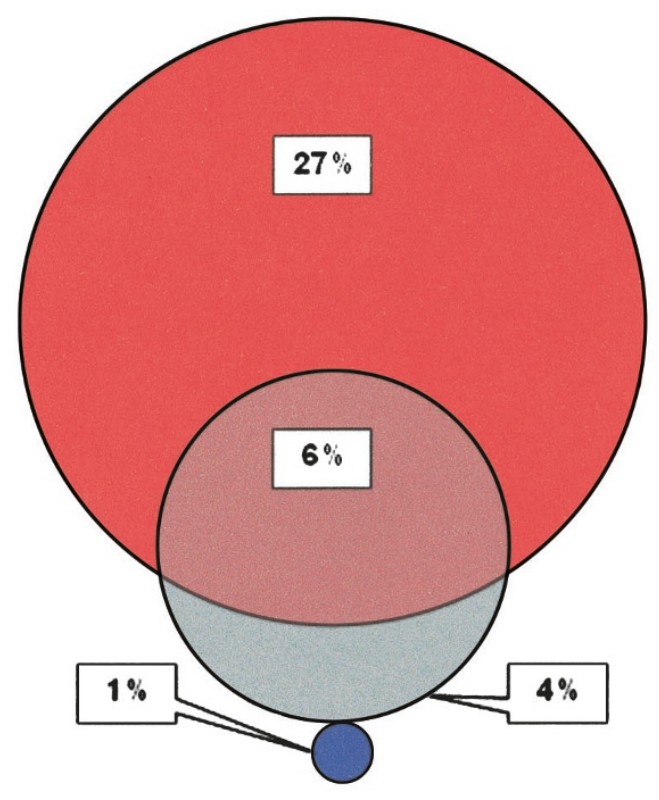

CD20+/CD30+/CD79a-/CD138- $(68 / 253,27 \%)$

$\mathrm{CD} 20+/ \mathrm{CD} 30+/ \mathrm{CD} 79 \mathrm{a}+\mathrm{CD} 138-(16 / 253,6 \%)$

CD20 - /CD30+/CD79a+/CD138- $\quad(10 / 253,4 \%)$

\section{CD20-/CD30+/CD79a-CD138+ $(2 / 253,0.8 \%)$}

FIGURE 3. Proportional expression of B-cell markers in Hodgkin and Reed-Sternberg cells of classical Hodgkin lymphoma.

$11,12)$. CD79a is noncovalently associated with surface immunoglobulins to constitute the B-cell antigen receptor complex on the surface of mature B cells (11). It can be speculated that down-regulated expression of CD79a in Hodgkin and ReedSternberg cells might be associated with the known lack of immunoglobulin mRNA transcription in Hodgkin and Reed-Sternberg cells because of absence of PU.1 along with Oct2 and BOB.1 $(34,35)$.

Only 2 of 253 classical Hodgkin lymphoma cases (1\%) expressed CD138, in contrast to reported results, using frozen tissue samples, of CD138expression in 45 to $100 \%$ of classical Hodgkin lymphoma (1, 2, 21). Obviously, the fundamental differences in techniques account for differences in the degree of expression of CD138 and make a direct comparison impossible.

In summary, the classical B-cell markers CD20 and CD79a are expressed in 33\% and $10 \%$ of classical Hodgkin lymphoma, respectively. Thirty-eight percent of classical Hodgkin lymphomas express at least one B-cell marker. Although classical Hodgkin lymphoma is considered exemplary of heteroge-

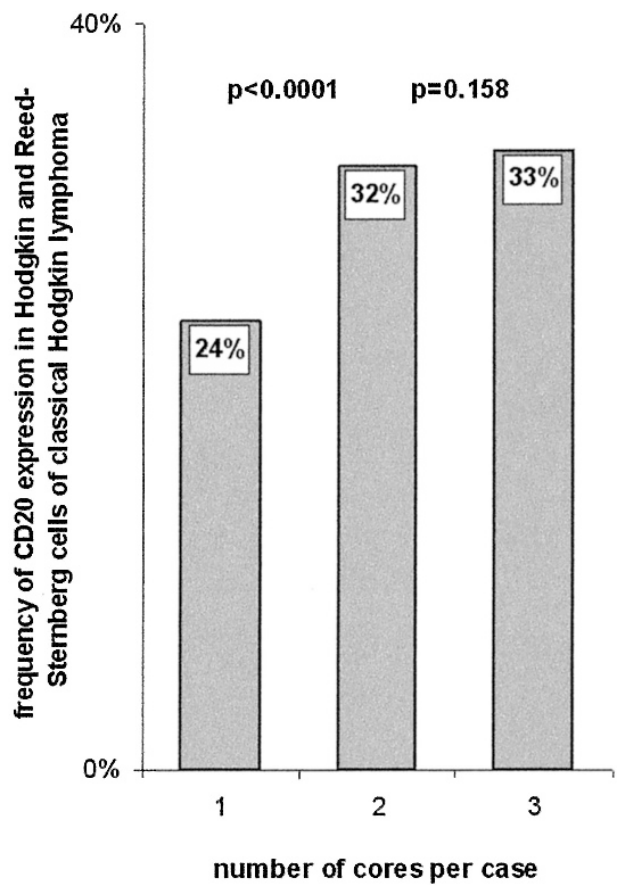

FIGURE 4. Cumulative expression of CD20 in Hodgkin and ReedSternberg cells of classical Hodgkin lymphoma after evaluation of one, two, and three tissue microarray cores. Three cores were present in the cases of Bologna and Zurich $(n=88)$.

neous tumors not suited for tissue microarray analysis, we demonstrate that the tissue microarray technology can be reliably applied for highthroughput analyses of focally and inconsistently expressed markers if at least two cores per case are examined.

\section{REFERENCES}

1. Carbone A, Gloghini A, Gattei V, Degan M, Improta S, Aldinucci D, et al. Reed-Sternberg cells of classical Hodgkin's disease react with the plasma cell-specific monoclonal antibody B-B4 and express human syndecan-1. Blood 1997;89: 3787-94.

2. Carbone A, Gloghini A, Gaidano G, Franceschi S, Capello D, Drexler HG, et al. Expression status of BCL-6 and syndecan-1 identifies distinct histogenetic subtypes of Hodgkin's disease. Blood 1998;92:2220-8.

3. Carbone A, Gloghini A, Aldinucci D, Gattei V, Dalla-Favera R, Gaidano G. Expression pattern of MUM1/IRF4 in the spectrum of pathology of Hodgkin's disease. Br J Haematol 2002; 117:366-72.

4. Cossman J, Annunziata CM, Barash S, Staudt L, Dillon P, He WW, et al. Reed-Sternberg cell genome expression supports a B-cell lineage. Blood 1999;94:411-6.

5. Foss HD, Reusch R, Demel G, Lenz G, Anagnostopoulos I, Hummel M, et al. Frequent expression of the B-cell-specific activator protein in Reed-Sternberg cells of classical Hodgkin's disease provides further evidence for its B-cell origin. Blood 1999;94:3108-13.

6. Kuppers R. Molecular biology of Hodgkin's lymphoma. Adv Cancer Res 2002;84:277-312.

7. Kuppers R, Hansmann ML, Rajewsky K. Clonality and germinal centre B-cell derivation of Hodgkin/Reed-Sternberg cells in Hodgkin's disease. Ann Oncol 1998;9 (Suppl 5):17-20. 
8. Pileri SA, Ascani S, Leoncini L, Sabattini E, Zinzani PL, Piccaluga PP, et al. Hodgkin's lymphoma: the pathologist's viewpoint. J Clin Pathol 2002;55:162-76.

9. Stein H, Delsol G, Pileri S, Said J, Mann R, Poppema S, et al. Classical Hodgkin lymphoma. In: Jaffe ES, Harris NL, Stein $\mathrm{H}$, Vardiman JW, editors. Pathology and genetics of tumours of the haematopoietic and lymphoid system. Lyon, France: IARC Press; 2001. p. 244-53.

10. Chittal SM, Caveriviere P, Schwarting R, Gerdes J, Al Saati T, Rigal-Huguet F, et al. Monoclonal antibodies in the diagnosis of Hodgkin's disease. The search for a rational panel. Am J Surg Pathol 1998;12:9-21.

11. Chu PG, Arber DA. CD79: a review. Appl Immunohistochem Mol Morphol 2001;9:97-106.

12. Korkolopoulou P, Cordell J, Jones M, Kaklamanis L, Tsenga A, Gatter KC, et al. The expression of the B-cell marker mb-1 (CD79a) in Hodgkin's disease. Histopathology 1994;24:511-5.

13. Molot RJ, Mendenhall NP, Barre DM, Braylan RC. The clinical relevance of L26, a B-cell-specific antibody, in Hodgkin's disease. Am J Clin Oncol 1994;17:185-8.

14. O'Grady JT, Stewart S, Lowrey J, Howie SE, Krajewski AS. CD40 expression in Hodgkin's disease. Am J Pathol 1994;144: 21-6.

15. Rassidakis GZ, Medeiros LJ, Viviani S, Bonfante V, Nadali GP, Vassilakopoulos TP, et al. CD20 expression in Hodgkin and Reed-Sternberg cells of classical Hodgkin's disease: associations with presenting features and clinical outcome. J Clin Oncol 2002;20:1278-87.

16. Schmid C, Pan L, Diss T, Isaacson PG. Expression of B-cell antigens by Hodgkin's and Reed-Sternberg cells. Am J Pathol 1991;139:701-7.

17. Torlakovic E, Torlakovic G, Nguyen PL, Brunning RD, Delabie J. The value of anti-pax-5 immunostaining in routinely fixed and paraffin-embedded sections: a novel pan pre-B and B-cell marker. Am J Surg Pathol 2002;26:1343-50.

18. Tzankov A, Krugmann J, Fend F, Fischhofer M, Greil R, Dirnhofer S. The prognostic significance of CD20 expression in classical Hodgkin lymphoma-a clinico-pathological study of 119 cases. Clin Cancer Res 2003;9:1381-6.

19. Vasef MA, Alsabeh R, Medeiros LJ, Weiss LM. Immunophenotype of Reed-Sternberg and Hodgkin's cells in sequential biopsy specimens of Hodgkin's disease: a paraffin-section immunohistochemical study using the heat-induced epitope retrieval method. Am J Clin Pathol 1997;108:54-9.

20. von Wasielewski R, Mengel M, Fischer R, Hansmann ML, Hubner K, Franklin J, et al. Classical Hodgkin's disease. Clinical impact of the immunophenotype. Am J Pathol 1997; 151:1123-30.

21. Watanabe K, Yamashita Y, Nakayama A, Hasegawa Y, Kojima $\mathrm{H}$, Nagasawa T, et al. Varied B-cell immunophenotypes of Hodgkin/Reed-Sternberg cells in classic Hodgkin's disease. Histopathology 2000;36:353-61.

22. Zukerberg LR, Collins AB, Ferry JA, Harris NL. Coexpression of CD15 and CD20 by Reed-Sternberg cells in Hodgkin's disease. Am J Pathol 1991;139:475-83.

23. Rudiger T, Ott G, Ott MM, Muller-Deubert SM, MullerHermelink HK. Differential diagnosis between classic
Hodgkin's lymphoma, T-cell-rich B-cell lymphoma, and paragranuloma by paraffin immunohistochemistry. Am J Surg Pathol 1998;22:1184-91.

24. Rehwald U, Schulz H, Reiser M, Sieber M, Staak JO, Morschhauser F, et al. Treatment of relapsed CD20+ Hodgkin lymphoma with the monoclonal antibody rituximab is effective and well tolerated: results of a phase 2 trial of the German Hodgkin Lymphoma Study Group. Blood 2003;101: 420-4.

25. Bubendorf L, Nocito A, Moch H, Sauter G. Tissue microarray (TMA) technology: miniaturized pathology archives for highthroughput in situ studies. J Pathol 2001;195:72-9.

26. Kononen J, Bubendorf L, Kallioniemi A, Barlund M, Schraml $\mathrm{P}$, Leighton $\mathrm{S}$, et al. Tissue microarrays for high-throughput molecular profiling of tumor specimens. Nat Med 1998;4: 844-7.

27. Garcia JF, Camacho FI, Morente M, Fraga M, Montalban C, Alvaro T, et al. Hodgkin's and Reed-Sternberg cells harbor alterations in the major tumor suppressor pathways and cell-cycle checkpoints: analyses using tissue microarrays. Blood 2003;101:681-9.

28. Hedvat CV, Hegde A, Chaganti RS, Chen B, Qin J, Filippa DA, et al. Application of tissue microarray technology to the study of non-Hodgkin's and Hodgkin's lymphoma. Hum Pathol 2002;33:968-74.

29. Pileri SA, Dirnhofer S, Went P, Ascani S, Sabattini E, Marafioti $\mathrm{T}$, et al. Diffuse large B-cell lymphoma: one or more entities? Present controversies and possible tools for its subclassification. Histopathology 2002;41:482-509.

30. Tzankov A, Zimpfer A, Lugli A, Krugmann J, Went P, Schraml $\mathrm{P}$, et al. High-throughput tissue microarray analysis of G1cyclin alterations in classical Hodgkin's lymphoma indicates overexpression of cyclin E1. J Pathol 2003;199:201-7.

31. Hertel CB, Zhou XG, Hamilton-Dutoit SJ, Junker S. Loss of B cell identity correlates with loss of B cell-specific transcription factors in Hodgkin/Reed-Sternberg cells of classical Hodgkin lymphoma. Oncogene 2002;21:4908-20.

32. Schwering I, Brauninger A, Klein U, Jungnickel B, Tinguely M, Diehl V, et al. Loss of the B lineage-specific gene expression program in Hodgkin and Reed/Sternberg cells of Hodgkin's lymphoma. Blood 2003;101:1505-12.

33. Mason DY, van Noesel CJ, Cordell JL, Comans-Bitter WM, Micklem K, Tse AG, et al. The B29 and mb-1 polypeptides are differentially expressed during human B cell differentiation. Eur J Immunol 1992;22:2753-6.

34. Jundt F, Kley K, Anagnostopoulos I, Schulze Probsting K, Greiner A, Mathas S, et al. Loss of PU.1 expression is associated with defective immunoglobulin transcription in Hodgkin and Reed-Sternberg cells of classical Hodgkin disease. Blood 2002;99:3060-2.

35. Stein H, Marafioti T, Foss HD, Laumen H, Hummel M, Anagnostopoulos I, et al. Down-regulation of BOB.1/OBF.1 and Oct2 in classical Hodgkin disease but not in lymphocyte predominant Hodgkin disease correlates with immunoglobulin transcription. Blood 2001;97:496-501. 